\title{
MEDIA SOSIAL DAN PERGULATAN MASYARAKAT MUSLIM INDONESIA DI INGGRIS: MERAYAKAN 'INGATAN' TENTANG TANAH AIR DALAM KONTEKS 'LOKAL'
}

\author{
M. Hilali Basya
}

\section{Abstrak}

Semakin meningkatnya teknologi komunikasi membuat cara berinteraksi masyarakat dan otoritas keilmuan mengalami pergeseran. Saat ini media sosial (medsos) seperti Facebook (FB) dan Whatsapp (WA) menjadi media yang paling sering digunakan dalam berkomunikasi, baik dalam bentuk percakapan singkat maupun diskusi yang mendalam. Meskipun percakapan secara langsung (face to face) antar individu dan diskusi dalam forum masih tetap terjadi, namun aktifitas semacam ini mengalami peningkatan dalam dunia maya terutama melalui FB dan WA. Konsekuensinya, sebuah diskusi yang sebelum dominasi medsos hanya melibatkan narasumber atau komentator secara terbatas dan sesuai dengan keahliannya, saat ini bisa menempatkan siapapun berada dalam posisi tersebut. Semua orang, termasuk yang awam sekalipun, bisa menjadi narasumber yang sepertinya sangat memahami sebuah topik. Artikel ini mengkaji tentang bagaimana masyarakat Muslim Indonesia di Inggris menggunakan medsos. Sebagian besar dari mereka adalah dosen, aktifis, ulama muda, birokrat, dan lain-lain yang sedang menempuh pendidikan tingkat S2 atau S3. Hidup dalam nilai-nilai, norma, dan kebudayaan yang berkembang dalam masyarakat Inggris yang tentu saja memiliki perbedaan dengan di Indonesia menjadi konteks sosial yang menarik untuk dikaji. Fokus yang ingin dijelaskan dalam artikel ini adalah bagaimana pengaruh konteks sosial tersebut terhadap cara masyarakat Muslim Indonesia di Inggris menggunakan media sosial.

Kata kunci: media sosial, tanah air, masyarakat muslim, budaya, muslim Indonesia 


\section{Gegar budaya Masyarakat Muslim Indonesia di UK}

Sepanjang tahun 2010 hingga 2016 jumlah masyarakat Indonesia yang menetap sementara di Inggris (UK) semakin banyak. Hal ini disebabkan, di antaranya, oleh meningkatnya pemberian beasiswa, terutama dari pemerintah Indonesia, yang terentang dari beasiswa yang diperuntukkan secara khusus untuk dosen hingga yang disediakan untuk masyarakat umum. Setiap tahun jumlah mahasiswa Indonesia yang belajar di Inggris bisa mencapai ratusan. Untuk yang studi lebih dari dua tahun, atau tingkat doktoral, biasanya membawa keluarga. Sehingga jumlah masyarakat Indonesia yang menetap di Indonesia bisa lebih banyak beberapa kali lipat dari penerima beasiswa itu sendiri. Belum lagi jika ditambah dengan para profesional serta akademisi yang bekerja di negara tersebut, serta mereka yang menikah dengan warga negara Inggris.

Sebagaimana umumnya para pendatang, masyarakat Muslim Indonesia mengalami masa adaptasi yang tidak mudah. Di masa-masa awal mereka harus menyesuaikan diri dengan kebudayaan yang berbeda. Bukan semata-mata perbedaan cuaca yang mengharuskan mereka untuk selalu melihat tingkat kedinginan suhu udara karena terkait dengan pakaian yang cocok untuk digunakan, melainkan juga yang terkait dengan kebiasaan sehari-hari seperti makanan, bahasa, dan cara membersihkan diri. Inggris bukanlah negara yang menyediakan bahan-bahan atau bumbu makanan yang 'ramah' untuk masyarakat Indonesia, apalagi yang beragama Islam. Di samping didominasi oleh gandum dan cita rasa yang 'datar' (tidak asin dan pedas), sebagian besar makanan masyarakat Eropa menggunakan bahan-bahan yang mengandung alkohol dan lemak babi. Sehingga masyarakat Muslim Indonesia cenderung berhati-hati dalam membeli makanan, baik yang siap saji seperti di restauran maupun yang mentah di pertokoan. Begitu pula terkait dengan proses membersihkan diri. Toilet-toilet di negara ini, baik yang di rumah maupun di tempat-tempat umum, biasanya bersifat kering dan hanya menyediakan tisu. Hal ini seringkali merepotkan masyarakat Muslim Indonesia ketika melakukan buang air besar (BAB). Dengan kata lain, masyarakat Indonesia yang baru datang ke Inggris dihadapkan dengan situasi yang menuntut mereka untuk beradaptasi dengan lingkungan baru tersebut.

Berada di negara yang mayoritas bukan beragama Islam dan berhadapan dengan nilai-nilai Eropa yang berbeda dengan yang di tanah airnya membuat masyarakat Muslim Indonesia mengalami keterkejutan budaya (culture shock), yaitu perasaan tersisolasi dari kebiasaan yang dialami di tempat asal mereka. Pada dasarnya perasaan semacam ini merupakan hal yang biasa dialami oleh 
mereka yang pergi meninggalkan kampung halamannya dan menetap di sebuah tempat baru yang secara budaya berbeda. ${ }^{1}$ Contoh yang mudah ditemukan adalah pada fenomena urbanisasi di mana masyarakat desa merantau atau migrasi ke kota-kota besar seperti Jakarta. Perbedaan nilai-nilai budaya yang berkembang dalam masyarakat Jakarta dengan daerah asal para masyarakat urban, membuat mereka mengalami 'keterkejutan' budaya seperti dalam hal bahasa, sikap, dan gaya hidup.

Namun situasi menetap di Inggris untuk beberapa lama (1-5 tahun) tidak bisa dibandingkan dengan migrasi dari desa ke kota, terutama terkait dengan persoalan keagamaan. Ketika waktu shalat tiba, misalnya, masyarakat Muslim Indonesia di Inggris tidak bisa mendengar suara adzan yang di tanah air biasanya terdengar jelas bersahutan dari masjid-masjid. Meskipun jumlah masjid relatif cukup untuk menampung umat Islam di Inggris, namun masjidmasjid tersebut tidak diperbolehkan untuk menggunakan pengeras suara. Sehingga suara adzan hanya bisa dinikmati oleh jama'ah yang berada di dalam masjid. Selain itu, untuk bisa mendapatkan tempat untuk menunaikan shalat berjamaah bukan sesuatu yang mudah sebagaimana di tanah air. Selain lokasi masjid yang relatif jauh, ruang-ruang dalam kampus ataupun perpustakaan tidak menyediakan fasilitas untuk shalat. Sehingga pada masa jam-jam 'bekerja' seringkali para mahasiswa menggunakan pojok-pojok perpustakaan atau kampus yang diasumsikan jarang dikunjungi oleh mahasiswa lain, yang memungkinkan mereka untuk melaksanakan shalat di tempat tersebut. Namun menggunakan tempat semacam ini tidak selalu diperbolehkan. Pernah suatu ketika seorang mahasiswa Indonesia ditegur oleh pengelola perpustakaan lantaran menggunakan pojokan ruang dalam perpustakaan untuk shalat.

Meskipun ada perasaan antusias untuk menetap beberapa tahun di sebuah negara Eropa, sebagian besar masyarakat Muslim Indonesia mengalami 'kegelisahan' budaya. Kegelisahan tersebut dapat dipahami mengingat masyarakat Muslim Indonesia, terutama kelas menengah dan terdidik, hidup dalam norma sosial yang relatif relijius. Kelas sosial ini adalah mereka yang mengalami islamisasi sebagai akibat menguatnya pengaruh kelompok Islamis atau revivalis seperti gerakan Tarbiyah, Hizbut Tahrir Indonesia (HTI), Jama'ah Tabligh, salafi, dan Partai Keadilan Sejahtera di Indonesia. ${ }^{2}$ Pandangan yang

1 Calleen Ward, Stephen Bochner, and Adrian Furnham, The Psychology of Culture Shock. Philadelphia: Routledge, 2001.

2 Ai Fatimah Nur Fuad, Islamism and Dakwah in Late Modern Indonesia: Official Discourses and Lived Experiences of Leaders and Members of the Tarbiyah Movemen. Tesis Doktoral di University of Leeds, 2017. 
selalu menjadikan Al-Quran dan Hadits Nabi serta pemaknaannya yang lebih literal dan simbolik, dan teladan umat Islam generasi awal (salaf) sebagai rujukan dalam segala aspek kehidupan sosial menjadi ciri dari menguatnya relijiusitas kelas menengah. Topik mengenai makanan yang tidak halal menjadi salah satu isu yang sering dibicarakan masyarakat Muslim Indonesia di Inggris. Hal ini bukanlah sesuatu yang mengejutkan, mengingat bahwa alkohol dan lemak babi adalah kandungan yang seringkali ada dalam makanan dan minuman di Inggris. Munculnya intensitas wacana mengenai hal tersebut didorong oleh terlihatnya kegagapan dalam menyikapi hal ini.

Begitu pula dengan pendidikan anak-anak mereka di sekolah di Inggris (Primary school) yang meskipun dikelola dalam nilai-nilai sekuler, tetapi tetap memberikan 'ruang' bagi identitas agama Katolik yang merupakan agama dominan masyarakat Inggris. ${ }^{3}$ Sekolah-sekolah di Inggris masih merayakan hari-hari besar agama Katolik. Meskipun banyak ahli seperti Graem Smith yang menyatakan bahwa perayaan hari besar agama dalam masyarakat Eropa, termasuk Inggris, lebih merupakan ekspresi kebudayaan ketimbang keyakinan agama, ${ }^{4}$ namun dalam perspektif masyarakat Muslim Indonesia semua itu adalah praktek ibadah keagamaan. Dalam sebuah pengajian di mana saya diundang menjadi narasumbernya, masyarakat Muslim Indonesia ini menanyakan bagaimana hukumnya membiarkan anak-anak mereka terlibat dalam perayaan hari-hari besar agama Katolik seperti Natal, apakah hal tersebut dapat merusak akidah anak-anak mereka atau tidak. ${ }^{5}$

'Ingatan' tentang kehidupan ritual Islam di tanah air juga menjadi salah satu yang menimbulkan 'kegelisahan'. Melaksanakan shalat berjamaah, terutama pada waktu Maghrib, adalah kebiasaan yang sudah menjadi tradisi yang hidup dalam masyarakat Indonesia. Meskipun anjuran untuk berjamaah ditekankan pada semua waktu shalat, namun jumlah jamaah di waktu shalat Maghrib biasanya lebih banyak dibandingkan dengan waktu-waktu shalat lainnya. Begitu pula menghadiri majlis taklim mingguan atau bahkan tabligh akbar, dan berkumpul bersama masyarakat dan keluarga memperingati hari-hari besar Islam (Isra' Mi'raj, Idul Fitri, Idul Adha, tahun baru Hijriyah, dll). Kebiasaan semacam ini menjadi 'ingatan' tentang 'rumah' atau tanah air, dan 'ingatan' ini memiliki makna yang lebih kuat ketika mereka hidup dalam situasi yang berbeda dan jauh dari tanah air. Dengan kata lain masyarakat Muslim Indonesia di Inggris

\footnotetext{
3 Graeme Smith, A Short History of Secularism. New York: I.B. Tauris, 2008.

4 Lihat Graeme Smith, A Short History of Secularism.

5 Kegiatan pengajian ini dilaksanakan oleh komunitas pengajian di York, Inggris, pada tahun 2014. Pertanyaan serupa juga diajukan pada pengajian di Leeds, Inggris, pada tahun 2013.
} 
bukan hanya hidup dalam norma sosial yang berbeda, melainkan juga dalam atmosfer spiritual yang berlainan. Semua ini menjadi konteks sosial yang sangat penting dan relevan untuk dipotret ketika ingin melihat bagaimana masyarakat Muslim Indonesia menggunakan media sosial.

\section{Media Sosial dan Merayakan 'Ingatan' Tentang Tanah Air}

Keterkejutan dan kegelisahan budaya mendorong munculnya perasaan untuk 'kembali' kepada suasana tanah air yang dirasakan 'hilang' dalam kehidupan di Inggris. Diskursus mengenai hal ini biasa ditemukan dalam kajian tentang masyarakat diaspora, mereka yang pindah dari negara asalnya karena perang, motivasi ekonomi, dan sebagainya yang kemudian menetap di negara lain. Lihat misalnya karya A Brah, Cartographies of Diaspora: Contesting Identities (1996), Baumann, Diaspora: Genealogy of Semantics and Transcultural Comparison (2000), Kim Knott and Sean McLoughlin, Diasporas: Concept, Intersection, Identities (2010).

Salah satu yang dilakukan oleh masyarakat Indonesia di Inggris dalam mengatasi keinginan untuk 'kembali' adalah dengan menjalin komunikasi yang erat dengan semua masyarakat Indonesia, di antaranya dengan yang beragama sama. Semakin banyak kesamaan latar belakang mereka di Indonesia, semakin kuat potensinya dalam mengembalikan 'ingatan' mengenai tanah air. Meskipun tidak selalu seperti ini yang terjadi pada setiap orang, namun kecenderungan tersebut dapat terlihat. Pada dasarnya tidak ada norma sosial ataupun norma agama yang mengatur secara ketat mengenai hal ini. Kecenderungan alami masyarakat membuat relasi antar individu yang memiliki kesamaan relatif lebih mudah terjalin. Kesamaan-kesamaan tersebut membantu mereka satu sama lain dalam memenuhi kerinduan suasana di tanah air. Dorongan untuk 'kembali' tersebut bersifat imajinatif. Meskipun tidak saling mengenal ketika di Indonesia, mereka disatukan oleh perasaan dan ingatan yang sama tentang tanah air.

Media sosial (medsos) menjadi salah satu perangkat yang mendukung masyarakat Muslim Indonesia merayakan 'ingatan' dan kerinduan terhadap suasana tanah air. Medsos adalah perangkat yang berbasis pada internet yang memungkinkan penggunanya untuk berkomunikasi, berbagi informasi, mengirimkan pesan dan foto, berdiskusi, dan seterusnya. ${ }^{6}$ Sejak awal, sekitar tahun 2008-2010 ketika saya

6 A. M. Kaplan \& M. Haenlein, “Users of the world, united! The challenges and opportunities of Social Media. Business Horizons, Vol. 53, No. 1 (2010). 
tengah menempuh studi Master di Universitas Leiden Belanda, Facebook (FB) telah menjadi medsos yang paling populer di kalangan mahasiswa Indonesia. Hingga tahun 2010-2016, ketika saya sedang menyelesaikan studi Doktoral di Universitas Leeds Inggris, FB masih menjadi medsos yang paling digemari oleh mahasiswa Indonesia.

Melalui FB penggunanya saling berbagi foto dan keterangan tentang aktifitas yang ada dalam foto, baik berupa kegiatan di dapur menyiapkan makanan, 'berburu' makanan yang sesuai dengan selera masyarakat Indonesia, maupun suasana berkumpul dengan masyarakat Indonesia lainnya di Inggris. Medsos semacam FB memang banyak digunakan untuk relasi pertemanan, penghargaan terhadap diri sendiri, dan kepuasan hidup. ${ }^{7}$ Temuan saya menunjukan bahwa FB membantu penggunanya (masyarakat Indonesia) 'merawat' dan 'merayakan' ingatan dan kerinduan mengenai ke-Indonesiaan dengan segala aspeknya. Bahasa yang digunakan, ekpresi atau respon terhadap foto-foto yang diunggah, termasuk isi dari foto-foto tersebut sedikit banyak mengekspresikan 'ingatan' tentang tanah air.

Munculnya 'whatsapp' (WA) yang mulai marak di tahun 2013 menambah keragaman pilihan jenis medsos. Aplikasi medsos yang terakhir ini, menurut opini saya sebagai orang awam, menggunakan lebih sedikit kuota internet ketimbang FB, dan karena itu juga lebih cepat dalam hal pengiriman dan penerimaan pesan. Dibandingkan dengan FB, proses komunikasi dengan WA lebih handal terutama terkait dengan komunikasi singkat yang intensif. Selain itu pencarian akun WA seseorang lebih mudah didapatkan sejauh nomor handphone (HP) orang yang dicari tersebut sudah diketahui. Terlepas dari kemudahan dan kehandalan WA, pengguna FB tetap tinggi. Hal ini disebabkan oleh adanya keunggulan tertentu yang ada pada FB. Saya sendiri menggunakan keduanya untuk tujuan yang berbeda. Untuk kebutuhan diskusi, FB lebih bisa diandalkan. Sedangkan untuk mengkoordinasikan sebuah kegiatan, WA lebih menjadi pilihan.

Meskipun medsos berpusat pada individu, ${ }^{8}$ karena memungkinkan setiap orang untuk membangun jaringan pertemanan sendiri, namun peran komunitas atau kelompok cukup signifikan dalam memayungi komunikasi dan diskusi

$7 \quad$ Nurdin dan Rusli, Social Media Adoption and Use within Indonesian Muslim Scholars: the Possibility of Use and Adoption for Dakwah Purposes. Makalah untuk Annual Conference on Islamic Studies (ACIS), 5-8 Oktober 2012, Surabaya.

8 B. Wellman, "From neighborhood to network," Communications of the ACM, Vol. 48, No. 10 (2005). 
masyarakat di Inggris melalui medsos group. Pertukaran informasi dan diskusi yang berlangsung dalam FB group atau WA group biasanya akan lebih tinggi tingkat partisipasinya. Terkait hal ini, paling tidak ada dua komunitas yang cukup besar di Inggris yaitu Persatuan Pelajar Indonesia (PPI) dan Keluarga Islam Britania Raya (KIBAR).

PPI merupakan organisasi mahasiswa/pelajar Indonesia. Sesuai dengan namanya, lembaga ini diperuntukan bagi mahasiswa atau mereka yang sedang menempuh pendidikan di Inggris dan karena itu yang bisa menjadi pengurusnya harus berstatus sebagai mahasiswa atau pelajar. Namun demikian, kegiatan-kegiatannya bersifat terbuka dan bisa dinikmati oleh semua lapisan masyarakat Indonesia. Lembaga ini terdiri dari tingkat pusat dan daerah. Menyadari pentingnya menginformasikan dan mengkomunikasikan kegiatan kepada pengurus dan anggotanya, mereka mengelola medsos di tingkat lokal (kota) dan pusat. Orang-orang yang tergabung dalam keanggotaan medsos ini terutama adalah mahasiswa dan pelajar. Melalui medsos tersebut PPI menginformasikan kegiatan yang akan diadakan dan membicarakan persoalanpersoalan keindonesiaan.

Sedangkan KIBAR adalah kelompok pengajian masyarakat Muslim Indonesia yang ada di tingkat lokal (kota) di Inggris seperti KIBAR Manchester, KIBAR Leeds, KIBAR Huddersfield, KIBAR London, dst. Di atas KIBAR-KIBAR lokal tersebut ada KIBAR tingkat pusat yang memayungi dan mengkoordinasikan kegiatan bersama yang rutin dilaksanakan beberapa kali dalam setahun. Dalam batas tertentu, ruang lingkup KIBAR lebih luas dibandingkan dengan komunitas PPI. Meskipun komunitas PPI tidak dibatasi oleh agama - tidak sebagaimana halnya KIBAR yang diperuntukkan khusus bagi Muslim - namun cakupan komunitas KIBAR melampaui usia dan status (mahasiswa atau nonmahasiswa). Sehingga siapapun, terlepas dari usia dan status keberadaannya di Inggris, bisa menjadi pengurus aktif komunitas KIBAR. Seperti halnya PPI, KIBAR juga mengelola medsos di tingkat lokal dan pusat.

Meskipun medsos yang dikelola oleh kedua komunitas ini memilki fokus yang berbeda, yang mana PPI menitikberatkan pada isu-isu keilmuan, sosial, dan politik, sedangkan KIBAR memokuskan pada masalah-masalah keagamaan, keduanya membantu masyarakat Indonesia merayakan 'ingatan' tentang dan kerinduan terhadap tanah air. Topik-topik yang dibicarakan dalam medsos yang dikelola PPI biasanya bersentuhan dengan kondisi di Indonesia. Hidup jauh dari tanah air membuat mereka menjadi lebih antusias membicarakan 
Indonesia daripada sebelumnya. Karena aktifitas membicarakan tersebut adalah ekpresi dari merayakan ingatan dan kerinduan terhadap tanah air. Adapun KIBAR berupaya mendiskusikan dan memposisikan keislaman mereka - yang sudah terbentuk sejak di Indonesia - dalam konteks kehidupan di Inggris. Dengan kata lain, upaya menghadirkan ingatan dan kerinduan dalam aspek keagamaan tersebut bukan semata-mata mempraktekan keyakinan yang sudah dimiliki, melainkan juga menimbang ulang sejauh mana keyakinan tersebut relevan dengan konteks kehidupan di Inggris. Terkait dengan aspek keagamaan ini akan dibahas lebih jauh pada bagian berikutnya.

\section{Merayakan 'Ingatan' Keagamaan dalam Konteks 'Lokal' Inggris}

Sebagai sebuah perkumpulan yang menyediakan pengajian atau kegiatan keislaman, KIBAR memiliki keuntungan tersendiri dibandingkan dengan perkumpulan non-agama seperti PPI. Keuntungan yang pertama adalah bahwa hampir semua masyarakat Islam Indonesia cenderung tidak menolak jika diajak untuk menghadiri pengajian. Bagi mereka, menolak pengajian seperti menolak ajakan kebaikan. Tidak mengherankan jika setiap tahun KIBAR di tingkat lokal (kota) mampu menghadirkan sebagian besar masyarakat indonesia yang baru tiba di Inggris. Selain itu, dan ini merupakan keuntungan yang kedua, mereka yang baru datang di negara besar Eropa ini membutuhkan komunitas dari negara asalnya yang dapat membantu mengenalkan wilayah, beradaptasi dengan lingkungan baru, atau segala hal yang terkait dengan perkuliahan di Inggris.

Perkumpulan ini bisa merangkul semua masyarakat Muslim Indonesia terlepas dari latar belakang organisasi keislaman atau pun partai politiknya di Indonesia. Miftah (bukan nama sebenarnya), misalnya, seorang mahasiswa doktoral di bidang ilmu kelistrikan, adalah seorang aktifis Tarbiyah dan Partai Keadilan Sejahtera (PKS). Dia langsung merasa nyaman dalam aktifitas KIBAR, bahkan menjadi salah satu anggota yang sangat aktif mendiskusikan tentang persoalan keislaman, keindonesiaan, dan konteks Inggris. Ada pula Jamal (bukan nama sebenarnya), seorang mahasiwa doktoral di bidang ilmu Humaniora, yang merupakan seorang pembina di sebuah pesantren di pulau Jawa dan sekaligus dosen dan memiliki latar belakang ke-NU-an yang sangat kuat. Tentu saja perkumpulan agama semacam ini bagi Jamal adalah seperti 'rumah', tempat dia menyumbangkan pengetahuannya. Selain mereka, banyak pula yang berasal dari Muhammadiyah yang sebagian besar berprofesi sebagai dosen di Perguruan Tinggi Muhammadiyah (PTM) di Indonesia. Sebagian mengambil program 
master dan sebagian lainnya doktor. Bidang studi yang diambil terentang dari ilmu sosial hingga ilmu alam. Ada pula yang memiliki latar belakang pegawai di pemerintahan seperti Polisi dan Birokrat dari departemen Keuangan, Pertanian, Pemerintah Daerah, dst. Sebagian besar dari mereka tidak berafiliasi kepada satu organisasi Islam mana pun. Karena itu KIBAR menjadi rumah bersama bagi warga NU, Muhammadiyah, Tarbiyah, dan lain-lain. Silaturahmi semua masyarakat Muslim Indonesia yang tinggal di Inggris - baik untuk keperluan pendidikan, menemani keluarga, ataupun bekerja - dapat terjalin secara erat melalui kegiatan KIBAR. Tidak mengherankan jika peran KIBAR dirasakan sangat signifikan bagi mereka.

Dilaksanakan minimal sekali dalam satu bulan, pengajian yang dilaksanakan oleh KIBAR di tingkat lokal dirasakan seperti ajang atau media untuk 'merayakan' ingatan dan kerinduan tentang Indonesia. Dapat dikatakan bahwa pengajian ini menjadi saat yang ditunggu oleh mereka. Dalam kegiatan ini, mereka masing-masing - terutama ibu-ibu yang senang memasak - akan menyuguhkan 'persembahan' terbaiknya untuk makanan bersama para jamaah pengajian. Karena itu pengajian ini juga menjadi kesempatan yang paling menyenangkan bagi mahasiswa Indonesia yang sudah sangat rindu dengan cita rasa masakan Indonesia. kerinduan semacam ini biasanya dirasakan oleh mereka yang masih lajang atau bapak-bapak yang tidak membawa serta istrinya. Kesibukan mereka dalam studi menyebabkan mereka hanya mengonsumsi makanan cepat saji yang umumnya menggunakan bahan utama gandum seperti roti. Saya sendiri, ketika sedang menempuh program S2 di Leiden (Belanda) tanpa istri, merasakan perubahan menu makanan dari nasi menjadi roti. Selain karena memang tidak biasa memasak, juga karena tidak ingin direpotkan dengan kegiatan memasak. Dan karena itu saya merasakan kegembiraan tersendiri ketika menghadiri acara pengajian semacam ini yang sudah bisa dipastikan akan menyajikan makanan khas Indonesia.

Meskipun kegiatan pengajian hanya dilaksanakan perbulan, namun komunikasi di antara sesama anggota atau jamaah terjalin cukup intensif, terutama karena adanya medsos (FB dan WA group) yang dikelola oleh KIBAR lokal. Melalui FB group para anggota saling bertukar informasi tentang di mana membeli bumbu yang sesuai dengan cita rasa Indonesia, daging yang dipotong sesuai dengan syariat Islam, restoran yang sesuai dengan anggaran, dan lain-lain. Melalui FB group ini pula para anggota bisa membuat janji untuk belanja bersama atau sekedar jalan-jalan menghabiskan akhir pekan. Dapat dikatakan bahwa melalui medsos group ini mereka melepaskan kerinduan akan suasana di tanah 
air. Meskipun sebagian besar dari mereka adalah para pejuang yang sedang mewujudkan mimpi dengan menimba ilmu di Inggris, sehingga bergaul dan membangun jaringan seluas-luasnya adalah salah satu cara untuk mewujudkan mimpi tersebut, namun kerinduan terhadap suasana tanah air tidak bisa dihentikan. Karena itu, berkomunikasi dengan sesama warga Indonesia melalui medsos group yang dikelola KIBAR adalah salah satu ekspresi dari kerinduan tersebut.

Medsos KIBAR menjadi ruang di mana para anggotanya tidak semata-mata merayakan ingatan tentang tanah air, melainkan juga menjadi medan kontestasi dalam mengkonstruksi bagaimana seharusnya menjadi Muslim Indonesia yang kaffah (sesuai dengan syariat Islam) di mana pun mereka berada, utamanya di Inggris. Seorang anggota medsos tersebut misalnya melontarkan pertanyaan tentang bagaimana mengatur jadwal shalat di saat jam perkuliahan atau pekerjaan tengah berlangsung. Berbeda dengan di tanah air, jadwal perkuliahan dan bekerja di Inggris tidak dirancang berdasarkan pertimbangan aktifitas ibadah umat Islam. Sehingga tidak jarang mereka harus menegosiasikan hal ini dengan cara menggabungkan (menjamak) shalat dalam satu waktu: Shalat Zuhur digabungkan dengan Ashar, Maghrib dengan Isya. Tetapi bagi sebagian lainnya, melakukan shalat jamak hanya bisa dilakukan jika seseorang melakukan perjalanan jauh. Sehingga, menurut mereka, para mahasiswa atau pekerja Indonesia tidak diperbolehkan menggabungkan shalat. Bagi kelompok ini, bahkan, shalat di awal waktu adalah prioritas. Sehingga kapanpun dan di manapun berada, diusahakan untuk melaksanakan shalat di awal waktu. Karena itu mereka berkesimpulan bahwa sebaiknya mahasiswa izin kepada dosennya atau pimpinan di perusahaannya untuk meninggalkan ruang atau aktifitas kerja guna melaksanakan shalat.

Di lain kesempatan ada seorang anggota yang mengirimkan sebuah berita tentang daftar makanan yang mengandung lemak babi dan alkohol, dan mengingatkan para anggota medsos tersebut untuk tidak mengonsumsi makanan dan minuman yang ada di daftar tersebut. Hal ini memunculkan respon dari beberapa anggota yang lain mengenai adanya fatwa dari seorang ulama untuk masyarakat Muslim yang tinggal di Eropa bahwa tidak semua makanan dan minuman yang mengandung alkohol diharamkan. Sejauh makanan atau minuman tersebut ketika dikonsumsi dalam jumlah banyak tidak memabukkan, maka tidak diharamkan. Karena itu fatwa ini menetapkan ukuran kandungan alkohol di bawah 5\% sebagai tidak memabukkan dan dibolehkan untuk dikonsumsi oleh umat Islam. Tentu saja fatwa ini mengundang perdebatan di kalangan anggota 
KIBAR. Karena sebagian besar umat Islam di seluruh dunia meyakini bahwa semua makanan atau minuman yang mengandung alkohol, baik dalam jumlah sedikit atau pun banyak, diharamkan.

Menjelang Ramadhan muncul pula diskursus mengenai bagaimana sebaiknya Muslim Indonesia berpuasa di negara yang rentang waktu dari Shubuh ke Magrib lebih panjang daripada Indonesia. Perlu untuk diketahui bahwa durasi berpuasa di Inggris pada musim panas sekitar 18-20 jam. Jadi pada saat musim tersebut waktu malam jauh lebih pendek, sedangkan waktu siang sangat panjang. Terkait topik ini ada anggota yang berargumen bahwa seorang Muslim dibolehkan untuk menyesuaikan puasanya dengan negara asalnya. Bahkan ada pula yang berpendapat bahwa sebagai seorang yang sedang berjuang keras menyelesaikan studinya, mahasiswa mendapatkan keringanan atau pengecualian untuk tidak berpuasa dan dapat menggantinya di luar bulan Ramadhan atau dengan membayar denda (memberi makan orang miskin misalnya).

Ketika merayakan ingatan dan kerinduan dalam aspek keagamaan tersebut sebenarnya mereka tidak sekedar meniru (copying or imitating) dan menghadirkan apa yang mereka percayai dan praktekan di Indonesia, melainkan juga 'memproduksi'. Upaya 'menghadirkan' ingatan dalam aspek keagamaan tersebut bersifat kontekstual dan merupakan proses 'memanggil' yang tidak stagnan, yang mengandung konsekuensi menafsirkan dan merekonstruksi apa yang diyakini dan dipraktekkan di tanah air, dan kemudian menghadirkannya dalam 'kebutuhan kekinian' dalam konteks kehidupan di Inggris.

\section{Kesimpulan}

Berada di sebuah negara di mana Muslim merupakan minoritas dan berhadapan dengan lingkungan dan nilai-nilai Eropa Barat yang tidak selalu sejalan dengan norma agama menyebabkan masyarakat Muslim Indonesia yang sedang menempuh pendidikan di Inggris mengalami keterkejutan budaya (culture shock). Keterkejutan tersebut membuat mereka merindukan 'suasana' tanah air. Hidup dalam suasana sosial seperti ini membuat 'ingatan' tentang tanah air memiliki makna yang lebih kuat. Keterkejutan budaya dan kerinduan terhadap suasana tanah air adalah konteks sosial yang sangat relevan untuk dipotret dalam memahami bagaimana masyarakat Muslim Indonesia menggunakan media sosial. 
Medsos menjadi salah satu perangkat yang mendukung masyarakat Muslim Indonesia merayakan 'ingatan' dan kerinduan terhadap suasana tanah air. Meskipun medsos berpusat pada individu, karena memungkinkan setiap orang untuk membangun jaringan pertemanan sendiri, namun peran komunitas atau kelompok cukup signifikan dalam memayungi komunikasi dan diskusi masyarakat di Inggris melalui medsos group. Komunitas PPI dan KIBAR memainkan peran penting dalam hal ini. Medsos yang dikelola PPI biasanya mendiskusikan kondisi sosial, ekonomi, dan politik di Indonesia, sedangkan KIBAR berupaya memposisikan keislaman mereka dalam konteks kehidupan di Inggris. Upaya reposisi tersebut mengandung arti bukan semata-mata mempraktekan keyakinan yang sudah dimiliki, melainkan juga menimbang ulang keyakinan tersebut agar relevan dengan konteks kehidupan di Inggris. Medsos yang dikelola KIBAR tidak semata-mata menjadi ruang dalam merayakan keindonesiaan, melainkan juga menjadi ruang kontestasi dalam mendefinisikan Muslim Indonesia dalam konteks kehidupan di Inggris.

\section{Daftar Pustaka}

Baumann, M. Diaspora: Genealogy of Semantics and Transcultural Comparison. Numen: International Review for the History of Religions, 47 (3), 2000.

Brah, A. Cartographies of Diaspora:Contesting Identities. London: Routledge, 1996.

Kaplan, A. M. \& Haenlein, M. "Users of the world, unite! The challenges and opportunities of Social Media. Business Horizons, Vol. 53, No. 1, 2010.

Knott, K. and McLoughlin, S. Diasporas: Concept, Intersection, Identities. New York: Zed Book, 2010.

Nurdin dan Rusli, Social Media Adoption and Use within Indonesian Muslim Scholars: the Possibility of Use and Adoption for Dakwah Purposes. Makalah untuk Annual Conference on Islamic Studies (ACIS), Surabaya, 5-8 Oktober 2012.

Smith, G. A Short History of Secularism. New York: I.B. Tauris, 2008.

Ward, C. Bochner, S. and Furnham, A. The Psychology of Culture Shock. Philadelphia: Routledge, 2001.

Wellman, B. "From Neighborhood to Network," Communications of the ACM, Vol. 48, No. 10, 2005. 